\title{
Causes of abortion in dairy cows in Uruguay
}

\author{
Melissa Macías-Rioseco ${ }^{2,3}$, Caroline Silveira ${ }^{2,3}$, Martin Fraga ${ }^{2}$, \\ Laura Casaux ${ }^{2,3}$, Andrés Cabrera ${ }^{4}$, María E. Francia $^{5}$ (D) Carlos Robello $^{4}$, \\ Leticia Maya ${ }^{6}$, Leticia Zarantonelli ${ }^{7,8}$, Alejandra Suanes ${ }^{9}$, Rodney Colina ${ }^{6}$, \\ Alejandro Buschiazzo ${ }^{8}$, Federico Giannitti ${ }^{2}$ (D) and Franklin Riet-Correa ${ }^{2 *}$ (i)
}

\begin{abstract}
Macías-Rioseco M., Silveira C., Fraga M., Casaux L., Cabrera A., Francia M.E., Robello C., Maya L., Zarantonelli L., Suanes A., Colina R., Buschiazzo A., Giannitti F. \& Riet-Correa F. 2020. Causes of abortion in dairy cows in Uruguay. Pesquisa Veterinária Brasileira 40(5):325-332. Instituto Nacional de Investigación Agropecuaria, Plataforma de Salud Animal, Estación Experimental INIA La Estanzuela, Ruta 50 Km 11, Colonia, 39173, Uruguay. E-mail: franklinrietcorrea@gmail.com

A case series study was conducted to determine the frequency of causes of abortion in dairy cattle in Uruguay. The sample size of 102 cases was composed of 53 fetuses, 35 fetuses with placentas, and 14 placentas without an associated fetus. All cases underwent gross and microscopic pathologic examinations as well as microbiological and serological testing. The etiology was determined in $54(53 \%)$ of cases, 51 of which were caused by infectious agents. Within the observed 102 cases, 30 (29\%) were caused by Neospora caninum, six $(6 \%)$ by Coxiella burnetii and two (2\%) by Campylobacter fetus subsp. venerealis. Bovine Parainfluenza-3 virus and Salmonella enterica serovar Newport caused one abortion each. Opportunistic bacteria (Escherichia coli, Streptococcus sp., Staphylococcus sp., Mannheimia sp., Trueperella pyogenes, and Providencia stuartii) were associated with 11 abortions. In two cases the fetal death was attributed to dystocia, and in one case the fetus had a congenital mesothelioma. Bovine viral diarrhea virus (BVDV) infection was identified in three fetuses; two of which were co-infected with and had typical lesions of $N$. caninum. No lesions were observed in the other fetus infected by BVDV. Leptospira interrogans was identified in one fetus without lesions. Despite the relatively low overall success rate in establishing an etiological diagnosis in cases of abortion in cattle, a systemic workup of bovine abortion is necessary to establish prevention and control strategies. This also facilitates monitoring and surveillance of reproductive diseases in dairy cattle, some of which represent a risk to public health.
\end{abstract}

INDEX TERMS: Dairy cattle, Uruguay, bovine abortion, Campylobacter fetus, Coxiella burnetii, Neospora caninum, cattle.

RESUMO.- [Causas de aborto em bovinos de leite no Uruguai.] Uma série de casos foi estudada para determinar a frequência de causas do aborto em bovinos leiteiros no Uruguai. A amostra, de 102 casos, foi composta por 53 fetos, 35 fetos

\footnotetext{
${ }^{1}$ Received on December 3, 2019.

Accepted for publication on December 26, 2019.

${ }^{2}$ Instituto Nacional de Investigación Agropecuaria (INIA), Plataforma de Salud Animal, Estación Experimental INIA La Estanzuela, Ruta 50 Km 11, 39173, Colonia, Uruguay. *Corresponding author: frcorrea@inia.org.uy

${ }^{3}$ Programa de Posgrado en Salud Animal, Facultad de Veterinaria, Universidad de la Republica, Av. 18 de Julio 1824-1850, Montevideo, 11200, Uruguay.

${ }^{4}$ Unidad de Biología Molecular, Institut Pasteur de Montevideo, Mataojo 2020, Montevideo, 11400, Uruguay.
}

com placentas e 14 placentas sem feto associado. Todos os casos foram submetidos a exames patológicos macroscópicos e microscópicos, além de testes microbiológicos e sorológicos. A etiologia foi determinada em 54 (53\%) dos casos, 51 dos

\footnotetext{
${ }^{5}$ Laboratory of Apicomplexan Biology, Institut Pasteur de Montevideo, Mataojo 2020, Montevideo, 11400, Uruguay.

${ }^{6}$ Laboratorio de Virología Molecular, Centro Universitario Regional Litoral Norte, Universidad de la República, Gral Fructuoso Rivera 1350, Salto, 50000, Uruguay.

${ }^{7}$ Unidad Mixta Pasteur, Instituto Nacional de Investigación Agropecuaria, Institut Pasteur de Montevideo, Mataojo 2020, Montevideo, 11400, Uruguay.

${ }^{8}$ Laboratorio de Microbiología Molecular y Estructural, Institut Pasteur de Montevideo, Mataojo 2020, Montevideo, 11400, Uruguay.

${ }^{9}$ División de Laboratorios Veterinarios, Ministerio de Ganadería, Agricultura y Pesca, Constituyente 1476, Montevideo, 11200, Uruguay.
} 
quais foram causados por agentes infecciosos. Nos 102 casos observados, 30 (29\%) foram causados por Neospora caninum, seis (6\%) por Coxiella burnetii e dois $(2 \%)$ por Campylobacter fetus subsp. venerealis. 0 vírus da Parainfluenza-3 e Salmonella enterica serovar Newport causaram um aborto cada. Bactérias oportunistas (Escherichia coli, Streptococcus sp., Staphylococcus sp., Mannheimia sp., Trueperella pyogenes e Providencia stuartii) foram associadas a 11 abortos. Em dois casos, a morte fetal foi atribuída a distocia e, em um caso, o feto apresentava mesotelioma congênito. A infecção pelo vírus da diarreia viral bovina (BVDV) foi identificada em três fetos; dois dos quais foram co-infectados e apresentavam lesões típicas de $N$. caninum. Não foram observadas lesões no outro feto infectado pelo BVDV. Leptospira interrogans foi identificada em um feto sem lesões. Apesar da relativamente baixa taxa de sucesso no diagnóstico etiológico nos casos de aborto em bovinos, é necessário o diagnóstico sistemático dos abortos para estabelecer estratégias de prevenção e controle. Isso também facilita o monitoramento e a vigilância de doenças reprodutivas em bovinos leiteiros, algumas das quais representam um risco para a saúde pública.

TERMOS DE INDEXAÇÃO: Aborto bovino, bovinos de leite, Uruguai, Campylobacter fetus, Coxiella burnetii, Neospora caninum.

\section{INTRODUCTION}

In Uruguay, dairy production is one of the most important economic activities of the agricultural sector. Abortion in dairy cattle increases the cost of reproduction, medical treatments, feeding, and culling and replacement rates (De Vries 2006). Abortions are gestational losses that occur between day 45 of pregnancy and the end of gestation (Campero et al. 2018). There is little information available about the prevalence of abortion in dairy cattle in South America. A study from Brazil examined 161 aborted bovine fetuses from Rio Grande do Sul and the cause of abortion was determined in $51.5 \%$ of the cases (Corbellini et al. 2006). Neospora caninum was the most commonly detected agent ( $23 \%$ of the cases) followed by bacteria in $17.4 \%$, fungi in $3.1 \%$ and viruses in $1.8 \%$ (Corbellini et al. 2006). The most recent study from Argentina, examined 150 bovine fetuses between 2004 and 2006 (Morrell 2010). The studied population was composed of dairy (23.4\%) and beef $(69.2 \%)$ cattle; the production class was unknown in the remaining cases (7.4\%). The diagnosis was determined in 52\% of the cases with $N$. caninum (14.7\%), Campylobacter fetus (9.3\%), Leptospira spp. (7.3\%), and Brucella abortus (6.7\%) being the most common agents. An etiological diagnosis was not achieved in the remainder $48 \%$ of the cases, although $25.3 \%$ of these had microscopic lesions suggestive of an infectious cause (Campero et al. 2018).

In Chile, a longitudinal study of 20 years examined a total of 494 bovine fetuses from 270 farms. Forty-eight percent of cases were from dairy farms, $10.1 \%$ from beef farms, and the rest from mixed production farms. The etiology was determined in $59.7 \%$ of the cases, and $52.2 \%$ of the cases had an infectious cause. The most commonly identified agent was Leptospira spp. in $25.2 \%$. About $22 \%$ of the cases had microscopic lesions compatible with $N$. caninum, and $B$. abortus was detected in $14.3 \%$. The two main viral agents reported were bovine herpesvirus- 1 in $13.4 \%$ and bovine viral diarrhea virus (BVDV) in $7.7 \%$ of the infectious cases (Meyer Zarzar 2013).

Infectious etiologies are among the most commonly reported abortigenic agents in cattle in Uruguay. A study conducted from 2002 to 2004 analyzed 431 aborted bovine fetuses from dairy (54\%) and beef (46\%) farms. In $41 \%$ of the cases with diagnosis, the abortion was attributed to leptospirosis based on the detection of leptospiral maternal antibodies, and $N$. caninum was identified in 36\%. Campylobacter fetus was reported in $13 \%$ of the cases, one of which, based on microscopic observation, was determined as coinfected with Tritrichomonas foetus. The bacterial etiology with the lowest reported frequency was B. abortus in 3\% of the cases. Lastly, about $23 \%$ of the examined fetuses did not have any macroscopic or microscopic lesions and were of undetermined cause (Easton 2006).

The diagnosis of bovine abortion is complex, and the diversity of causes cannot be identified despite extensive laboratory testing (Antoniassi et al. 2013, Clothier \& Anderson 2016). Bovine abortion has been considered a syndrome because of the complexity of their causes (Anderson et al. 1990, Campero et al. 2003). Fetal and placental autolysis is common, precludes the observation of lesions interfering with the successful identification of infectious agents. The circulation of more than one abortigenic agent in the same herd could represent another difficulty in the diagnosis of bovine abortion, particularly in epidemic outbreaks (MacíasRioseco et al. 2019a). Likewise, bacterial cultures from fetal tissues and placentas are frequently contaminated with nonpathogenic or opportunistic bacteria (Clothier \& Anderson 2016), making interpretation of results difficult, particularly in cases without lesions typical of bacterial infection. Nonetheless, a plethora of diagnostic approaches such as necropsy, histology, immunohistochemistry, bacteriology, virology, immunology and molecular biology assays, aid in the diagnosis of bovine abortion.

Achieving the etiologic diagnosis in bovine abortion is challenging mainly when adequate diagnostic tests are not available, particularly when caused by infrequent or opportunistic agents, or agents that are nonculturable by traditional microbiological methods. A study of 655 cases of bovine abortion in California, revealed that about $20 \%$ of the examined fetuses did not have any specific lesions (Clothier \& Anderson 2016). Moreover, about $11.7 \%$ of these cases had macroscopic and/or microscopic lesions (abomasitis, pleuritis, peritonitis, hepatitis, splenitis, myocarditis, encephalitis and thymitis) with no pathogens identified. When a lesion is identified but there is no etiology found, infectious agents that are rarely detected in cases of abortion or difficult to isolate should be considered. The ideal diagnostic tests may be unavailable or perhaps the appropriate samples are not submitted to the laboratory for testing. Ideal samples for bovine abortion investigation are the aborted fetus, placenta, and serum from aborted and matched pregnant non-aborted dams. The objective of this work was to identify and determine the relative frequency of etiologies in cases of abortion in dairy cattle submitted to a veterinary diagnostic laboratory in Uruguay from 2015 to 2018. 


\section{MATERIALS AND METHODS}

Case selection and case definition. From January 1st, 2015 to November 1st, 2018, bovine abortion cases were processed at the veterinary diagnostic laboratory of the Platform of Animal Health, at the National Institute of Agricultural Research in La Estanzuela experimental station, Colonia, Uruguay. Cases were either submitted to the laboratory by veterinary practitioners or collected directly from the dairy farms by our team upon the practitioner's request. Cases were defined as: 1) an aborted fetus; 2) an aborted fetus with its placenta; and 3) a placenta from an animal that aborted. Cases submitted from the same farm at the same time and composed of two or more fetuses and/or placentas from different dams were categorized as different cases. The etiologic diagnosis was determined by the association of the identified pathogen and the presence of compatible gross and/or microscopic lesions (see section on diagnostic tests below). Cases with an identified pathogen but with no lesions, and cases with lesions but with no causative agent identified were categorized as abortion cases of undetermined etiology. Information on sex, date of submission, geographic location of the farm, breed and age were obtained from the veterinarians and farmers. The fetal age in days was estimated based on the crown-to-rump length and other gross characteristics of the fetuses, and further categorized in first, second or third trimester of gestation. Cases were also categorized by the degree of autolysis as mild, moderate or severe.

Pathologic examination. Macroscopic evaluation of the placentas and fetuses were done by veterinary laboratory diagnosticians with pathology training. Samples of liver, kidneys, adrenal glands, spleen, lymph nodes, thymus, lungs, heart, brain, skeletal muscles, forestomachs, abomasum, cecum, spiral colon, duodenum, jejunum, ileum, and placenta (when available), were fixed in 10\% neutral buffered formalin, embedded in paraffin, sectioned at 4-6 $\mu \mathrm{m}$, and stained with hematoxylin and eosin for microscopic examination. Depending on the initial microscopic examination and assessment of lesions and/or results of other diagnostic tests, and immunohistochemical (IHC) procedures for the detection of Coxiella burnetii, Chlamydia spp., BVDV, bovine parainfluenza-3 virus, and/or N. caninum were performed in selected tissues in some cases (see below). At necropsies, samples were collected for bacteriology, molecular biology, and serologic testing (see below).

Diagnostic tests. Placenta, liver, lung, and abomasal fluid from all cases were inoculated onto blood and MacConkey agars (Oxoid, Basingstoke, Hampshire, England) and incubated at $37^{\circ} \mathrm{C}$ in aerobic conditions. In addition, samples were also inoculated onto Skirrow agar (Oxoid, Basingstoke, Hampshire, England) and incubated in anaerobic jars (CampyGenTM, Oxoid, Basingstoke, Hampshire, England), at $37^{\circ} \mathrm{C}$ for 2 to 7 days in an atmosphere of $5-10 \%$ of oxygen and $5-10 \%$ carbon dioxide (Chaban et al. 2013). In the cases where bacterial isolates were obtained, bacterial identification was performed either by routine biochemical test or by sequencing the $16 \mathrm{~S}$ rRNA. Placenta, liver, kidney, aqueous humor, and abomasal fluid were also spiked into Leptospira Medium Base Ellinghausen, McCullough, Johnson and Harris (EMJH) and incubated in aerobiosis at $29^{\circ} \mathrm{C}$ for up to 6 months (Zarantonelli et al. 2018). Fetal pericardial fluid (when available) was analyzed by microagglutination test (MAT) to detect antibodies against Leptospira serovars Grippotyphosa, Icterohaemorrhagiae, Pomona, Canicola, Hardjo Bovis, Hardjo Prajitno and Wolfii at a cutoff point of 1/10 (Zarantonelli et al. 2018).

PCR for the lipL32 gene of pathogenic Leptospira species was done from the 102 cases, as homogenates of liver, kidney and, placenta (when available). The primers LipL32F (5'-ATCTCCGTTGCACTCTTTGC-3') and LipL32R (5'-ACCATCATCATCATCGTCCA-3') were used. The mix was exposed at $95^{\circ} \mathrm{C}$ for $5 \mathrm{~min}$, then 35 cycles of $30 \mathrm{sec}$ at $95^{\circ} \mathrm{C}$, for denaturation, and $30 \mathrm{sec}$ at $58^{\circ} \mathrm{C}, 60 \mathrm{sec}$ at $72^{\circ} \mathrm{C}$, and $7 \mathrm{~min}$ at $72^{\circ} \mathrm{C}$ for annealing and extension (Zarantonelli et al. 2018).

Direct immunofluorescence (DIF) for Campylobacter fetus was done on impression smears from all placentas, abomasal fluid, lung, and liver. Smears were fixed in ethanol at room temperature and incubated with an anti-Campylobacter antibody conjugated with fluorescein isothiocyanate (FITC) (Biotandil, Tandil, Buenos Aires, Argentina) (Figueiredo et al. 2002). Similarly, DIF for Leptospira spp. was performed on impression smears from kidney, liver, aqueous humor, and placenta using LEP-FAC multivalent rabbit FITC-bound antibody (NVSL, Ames/IA, USA). The smears were visualized in a fluorescence microscope (AxioLab.A1, Carl-Zeiss, Germany) set at wavelengths of $495 \mathrm{~nm}$ excitation and $519 \mathrm{~nm}$ emission.

Additionally, abomasal fluid or placenta smears were examined directly under dark field microscopy to assess for agents morphologically compatible with Campylobacter spp., Leptospira spp. and Tritrichomonas foetus. PCR for bovine herpesvirus-1 (BHV-1) and RT-PCR for BVDV were performed in pools of liver, lung, spleen, kidney, thymus, heart, brain, placenta, lymph node, and adrenal gland obtained individually in all cases that included fetuses. For BVDV, the primers V324mod (5' - ATGCCCWTAGTAGGACTAGCA-3') and V326mod (5' -WCAACTCCATGTGCCATGTAC-3') were used based on Maya et al. (2016). Briefly, the mix was exposed at $95^{\circ} \mathrm{C}$ for $10 \mathrm{~min}$, then 45 cycles of $10 \mathrm{sec}$ at $95^{\circ} \mathrm{C}$, for denaturation, and $60 \mathrm{sec}$ at $50^{\circ} \mathrm{C}$ for annealing and extension. The primers gCBoHV F (5'-GCGGGGGCTCGCCGAGGA-3') and gCBoHV R (5'-GGAGCGCACGGTCAGGGGC-3') were used for BHV-1 PCR. The mix was exposed at $95^{\circ} \mathrm{C}$ for $5 \mathrm{~min}$, then 35 cycles of $30 \mathrm{sec}$ at $95^{\circ} \mathrm{C}$, for denaturation, and $30 \mathrm{sec}$ at $60^{\circ} \mathrm{C}$ for annealing, $1 \mathrm{~min}$ at $72^{\circ} \mathrm{C}$ for extension and lastly, $10 \mathrm{~min}$ at $72^{\circ} \mathrm{C}$ (Silva et al. 2007).

The IHC for BVDV antigen detection was done only in cases with a positive RT-PCR result for this virus. Heat induced antigen retrieval was performed in a decloaking chamber (Biocare Medical). A mouse IgG anti-BVDV (VMRD, Pullman/WA) was applied as primary antibody, followed by anti-mouse IgG horseradish peroxidase (HRP)-labeled polymer (DAKO, Santa Clara/CA), and 3-amino-9-ethylcarbazole (AEC, DAKO, Santa Clara/CA) as the chromogen. In one fetus with pneumonia with syncytial cells, RT-PCR for bovine parainfluenza-3 (BPI-3) virus was done from frozen samples of lung and the amplification products were sequenced, as we have previously described for this same case (Macías-Rioseco et al. 2019b).

Based on the presence of compatible lesions (necrotizing and suppurative placentitis with intratrophoblastic bacteria), IHC for $C$. burnetii and Chlamydia spp. were done in selected cases (Dilbeck \& McElwain 1994, Giannitti et al. 2016). When a positive result for C. burnetii by IHC was obtained, PCR was used for detection of this pathogen in the formalin-fixed paraffin-embedded (FFPE) blocks containing placenta (Lorenz et al. 1998). The IHC procedures for Chlamydia spp. and $C$. burnetii and the PCR in FFPE placenta in these same cases has recently been published by our group (MacíasRioseco et al. 2019c).

Immunohistochemistry and PCR for detection of $N$. caninum antigen and DNA, respectively, were done only in cases with compatible histologic lesions in the brain, heart, placenta and/ or liver. For the IHC, a goat polyclonal antibody (VMRD, Pullman, WA) against $N$. caninum was used as a primary antibody, antigoat IgG horseradish peroxidase (HRP)-labeled polymer (Vector polymer enzyme detection kit, Burlingame/CA) as the secondary antibody, and 3-amino-9-ethylcarbazole as the chromogen (DAKO, Santa Clara/CA). The PCR for $N$. caninum was done following the 
procedure described by Yamage et al. (1996). PCR products were visualized on $1 \%$ agarose gel electrophoresis stained with SYBR safe (Invitrogen, USA), purified with QIAquick PCR Purification Kit and sequenced in house at the sequencing service of the "Institut Pasteur de Montevideo", Uruguay. All tests were performed with appropriate positive and negative controls for each run.

Statistical methods. The results of the pathologic examinations and diagnostic tests, as well as the fetal gestational age, degree of autolysis and the department where the dairy farm was located were recorded in a database using Microsoft Excel, and descriptive statistics were obtained.

\section{RESULTS}

The series was composed of 102 cases; 53 of the cases were only fetuses, 35 were placentas with fetuses, and 14 were placentas only. The 102 cases were submitted from 45 different farms. The maximum number of cases submitted from the same farm was 28. Most of the cases were submitted from the department of Colonia with 58 cases, followed by San Jose (17), Canelones (6), Lavalleja (4), Soriano (2), Florida (2), and Rio Negro (2). The department was not recorded in 11 cases. The degree of autolysis was recorded in 95 cases: 59 had mild autolysis, 28 had moderate autolysis, and eight were severely autolyzed, five of these were mummified fetuses for which no etiology was determined. Forty-two fetuses were in the second trimester of gestation at the time of the abortion, followed by 33 cases in the third trimester and five in the first trimester.

The etiology of the abortion was determined in 54 (53\%) cases, while the cause was undetermined in 48 (47\%). of the cases with undetermined etiology, 11 (23\%) had inflammatory and/or necrotizing lesions in various tissues suggesting an infectious process, although no agent could be identified in the tissues by the set of diagnostic tests performed in the study. Of the 54 cases that had an etiologic diagnosis, 51 (94.4\%) were caused by infectious agents. Thirty-eight of the 51 (74.5\%) were caused by agents that are primarily recognized as reproductive pathogens, one was caused by BPI-3 virus and another by Salmonella enterica serovar Newport. The remainder 11 cases $(21.5 \%)$ were associated with opportunistic bacteria. The 38 cases caused by reproductive pathogens included $N$. caninum (30 cases), $C$. burnetii ( 6 cases), and $C$. fetus subsp. venerealis ( 2 cases). Of the 11 cases caused by opportunistic pathogens, Escherichia coli was identified in 4 cases, Streptococcus spp. in 2 cases, and Streptococcus pyogenes, Staphylococcus sp., Trueperella pyogenes, Providencia stuartii, and Mannheimia sp. were identified in one case each. Placentitis, bronchopneumonia, and/or hepatitis were the main histologic lesions observed in association with these opportunistic agents. Regarding the three cases with non-infectious causes (5.6\% of the 54 cases with an identified cause), in two cases the death of the fetuses was due to dystocia and in one case the abortion was caused by a congenital mesothelioma affecting the abdominal and pelvic viscera that was extensive enough to be considered incompatible with life. The percentage of diagnosis was variable according to the material sent to the laboratory. When only the fetus was sent, the diagnosis was made in $50.9 \%$ of the cases; when the fetus and placenta were received the diagnosis was made in $62.8 \%$ of the cases, and when only the placenta was available the diagnosis was made in $37.7 \%$ of the cases (Table 1).

The 30 abortions caused by N. caninum (55.6\% of the 54 cases with determined etiology) were from different dairy farms, accounting for $53.3 \%$ of the 45 farms included in the study. Of the six abortions caused by $C$. burnetii, five were from the same farm. Campylobacter fetus subsp. venerealis was the etiology in 2 cases from different farms.

The number of cases submitted per farm varied from one to 28 , and the number of causes of abortion diagnosed on each farm varied from one to four (Fig.1). In farm 42, four different etiologic agents causing abortion were identified: $N$. caninum in two cases, $C$. burnetii in five, Salmonella enterica serovar Newport in one, and BPI-3 virus in another. In farm 43 , five aborted fetuses were sent to the laboratory during an abortion outbreak, one abortion was caused by $C$. fetus subsp. venerealis and two by $N$. caninum; in the other two fetuses the cause of abortion was undetermined (MacíasRioseco et al. 2019a). In farm 1, one abortion was caused by $N$. caninum, another by E. coli, and one was due to dystocia. In farm 17, an etiologic diagnosis could only be confirmed in one of nine examined cases.

The cases caused by $N$. caninum corresponded to abortions within the second trimester of gestation. The 30 fetuses aborted by neosporosis had typical lesions including nonsuppurative encephalitis and gliosis (29 fetuses), myocarditis (24), myositis (diaphragm or tongue) (20) hepatitis (15), interstitial nephritis (10) and/or interstitial pneumonia (6). Additionally, placenta was submitted along with the fetus in 10 of these 30 cases, 7 of which had placentitis. The six abortions caused by $C$. burnetii corresponded to full-term gestations and had moderate to severe multifocal necrotizing and suppurative placentitis with intralesional and intratrophoblastic bacteria, and only one case had mild neutrophilic alveolitis. No cases of coxiellosis were diagnosed in cases where no placenta was available for examination. One case of abortion due to C. fetus subsp. venerealis had a non-suppurative fibrinous epicarditis and myocarditis; the placenta was not available for examination. The other case of $C$. fetus subsp. venerealis abortion had suppurative placentitis with arteriolitis and fibrinoid necrosis, neutrophilic bronchiolitis and alveolitis along with neutrophilic and histiocytic portal hepatitis. Suppurative and necrotizing placentitis was observed in cases associated with E. coli, T. pyogenes, and S. enterica serovar Newport. The latter also had intralesional coccobacilli in the placenta, along with minimal to mild neutrophilic lymphadenitis. In one case caused by Staphylococcus sp., the agent was isolated from the skin and from abomasal fluid, the fetus had diffuse hyperkeratosis, neutrophilic, histiocytic and fibrinous synovitis, along with moderate non-suppurative interstitial pneumonia

Table 1. Percentages of cases with diagnosis and without diagnosis within type of sample submitted

\begin{tabular}{lccc}
\hline \multicolumn{1}{c}{ Sample submitted } & With diagnosis & Without diagnosis & Total \\
\hline Fetus & $27(50.9 \%)$ & $26(49.1 \%)$ & 53 \\
Fetus and placenta & $22(62.8 \%)$ & $13(37.2 \%)$ & 35 \\
Placenta & $5(35.7 \%)$ & $9(66.3 \%)$ & 14 \\
Total & 54 & 48 & 102
\end{tabular}


with neutrophilic alveolitis and mild non-suppurative meningoencephalitis. One case caused by Mannheimia sp. had a moderate lymphohistiocytic and neutrophilic placentitis with multifocal trophoblastic necrosis. BPI-3 virus caused multifocal neutrophilic and histiocytic alveolitis (pneumonia) with a moderate number of syncytial cells in the lungs and intestines in one case (Macías-Rioseco et al. 2019b). In cases with lesions but without an identified etiology, the lesions consisted of myocarditis, myositis, glossitis, cerebral gliosis, nephritis, pneumonia, and hepatitis.

Brucella abortus was not isolated in any case. Other bacterial agents such as Acinetobacter lwofii, Aerococcus urinae, Providencia sp., Yersinia sp., E. coli, Enterobacter sp., Corynebacterium sp. and Serratia sp. were isolated on bacterial cultures, but due the absence of associated lesions expected for bacterial infections, these abortions were classified as of undetermined etiology. The gene lipL32 of Leptospira spp. was detected in one sample of liver by PCR, the causality of the abortion was not attributed to this agent based on the lack of fetal lesions generally associated with leptospirosis. None of the tested fetal pericardial and/or thoracic fluids were reactive at the cutoff reference point for MAT for Leptospira spp. antibodies, including the case that was PCR-positive for this agent. Leptospira spp. culture was negative in all cases. PCR for BHV-1 was negative in all cases. RT-PCR for BVDV was positive in three cases; two of them were in co-infection with $N$. caninum, and the protozoon was determined as the causal agent based on the presence of typical lesions and the positive results for $N$. caninum PCR and IHC. Due the absence of lesions, the etiology on the third BVDV-positive case was categorized as undetermined. Two of the three BVDV PCRpositive fetuses were aborted in the second trimester and the other in the third trimester of gestation. To assess whether these fetuses congenitally infected with BVDV harbored high antigenic viral loads and thus were persistently infected, IHC for BVDV antigen detection was performed in several tissues (brain, lung, heart, thymus, liver and small intestine), with negative results in all three cases (data not shown). Based on these results, we interpreted that the fetuses were suffering from transient BVDV infections.

\section{DISCUSSION}

In this case series, the most common cause of abortion was $N$. caninum. A previous study in Uruguay, showed a seroprevalence of $N$. caninum of $22 \%$ in dairy cows and $92 \%$ of the herds (Piaggio 2006). Our series was composed mainly of fetuses of gestational age in the second trimester, which may be explained in part by the high frequency of neosporosis. Abortions due to $N$. caninum are most commonly seen during the second and third trimesters of gestation (McAllister 2016). Our results and the high proportion of farms with seropositive cattle to $N$. caninum suggest that abortions caused by this agent potentially occur in most farms (Silveira 2019).

Coxiella burnetii is rarely reported as a cause of abortion in cattle (Agerholm 2014). In our study, this agent was observed as a sporadic cause of abortion (only one case in one dairy farm) and as a cluster of five cases within a period of five months in another farm (Macías-Rioseco et al. 2019c). We were able to identify abortions due to coxiellosis based on the microscopic



Fig.1. Frequency of different etiologies affecting each farm and total number of cases submitted per farm. 
evaluation of the placenta followed by IHC along with PCR for C. burnetii. In all cases, the diagnosis of coxiellosis was based on the presence of necrotizing and suppurative placentitis with intralesional and intratrophoblastic bacteria identified as $C$. burnetii. The presence of lesions associated with the bacteria is key to the diagnosis of coxiellosis (Bildfell et al. 2000, Hazlett et al. 2013) since $C$. burnetti can be identified by PCR in the placenta of ruminants without being the cause of abortion (Hazlett et al. 2013).

These results suggest that $C$. burnetii is a previously undiagnosed cause of abortion in dairy cattle in Uruguay and highlight the importance of examining the placenta in aborted cattle to achieve this diagnosis. The presence of antibodies against $C$. burnetii in slaughterhouse workers from Uruguay has been associated with history of clinical signs, and a clinical case of endocarditis (Moreira et al. 1987), showing that this agent is an occupational hazard for veterinarians and slaughterhouse workers. Also, antibodies against $C$. burnetii have been found in different animal species in this country, including cattle (Moreira et al. 1987).

Campylobacter fetus subsp. venerealis was observed in relative low frequency ( 2 cases of 54 with an identified etiology), which could be due the fact that this venereal transmitted agent is usually a cause of infertility and causes abortion only sporadically (Michi et al. 2016, Silva et al. 2007). Abortions are more commonly detected between the fourth and sixth months of gestation (Silveira et al. 2018). A national survey that evaluated 340 dairy farms identified that about $50 \%$ of the farms use only natural breeding with bulls, and an additional $20 \%$ use a combination of natural breeding and artificial insemination (INALE 2014). This suggest that campylobacteriosis may still be a problem in dairy farms in Uruguay.

As seen in this study, several causes of abortion were diagnosed in some farms, which indicates that the diagnosis of a primary cause of abortion, including neosporosis, campylobacteriosis, or coxiellosis, does not exclude other causes of abortion. Hence, it is recommended to attempt the diagnosis in as many cases as possible in order to increase the chances of detecting other abortifacients and better understand the situation of each farm.

In our case series, only one of the tested fetuses was positive for Leptospira spp. by PCR on a liver sample Sequencing confirmed that the infection corresponded to the species L. interrogans. Fetal pericardial and/or thoracic fluids were antibody-negative by MAT in all fetuses, including the PCRpositive one. DIF and/or dark field microscopy for the detection of leptospires were also negative in all fetal imprints and abomasal fluids. While Leptospira spp. cannot be excluded as a relevant abortigenic pathogen in cattle in Uruguay, our study did not allow for confirmation of Leptospira spp. as a cause of abortions following the diagnostic criteria and case definition we established. Many Leptospira species and serovars have recently been isolated from bovine urine and blood samples in Uruguay, including L. interrogans serogroup Pomona serovar Kennewicki (20 strains), L. interrogans serogroup Canicola serovar Canicola (1 strain), L. borgpetersenii serogroup Sejroe serovar Hardjo (10 strains) and L. noguchii ( 9 strains, belonging to a variety of serogroups) (Zarantonelli et al. 2018). According to that study, $20 \%$ of the almost 1,000 sampled cows were eliminating Leptospira spp. in the urine
(Zarantonelli et al. 2018). It is striking that with such a high number of animals eliminating leptospires in the urine, the present study did not find abortions caused by leptospirosis. It cannot be ruled out that Leptospira-induced abortions might occur with no detectable infection of the fetus or placenta and be caused by other mechanisms including the pathogentriggered inflammatory cascade (Raghupathy 2001, Zi et al. 2015). Examples of such abortigenic scenarios include subclinical infections in the mother due to urinary tract infection (Schieve et al. 1994), periodontitis (Zi et al. 2015), bacterial vaginosis (Giakoumelou et al. 2016), among other pathologies. In animals such inflammatory processes linked to premature birth or miscarriage have also been described e.g. in bovine viral diarrhea (Moennig \& Liess 1995), suggesting that different pathogen strains can produce different clinical outcomes. The role of the different Leptospira species found in the urine of healthy cattle as a cause of sporadic abortions and other reproductive failures should thus be further investigated (Zarantonelli et al. 2018). In the present series of abortions, most cases corresponded to sporadic abortions and only few outbreaks were studied. It is possible that infections by some Leptospira species and/or specific serovars may cause abortion outbreaks in herds, which probably were not subjected to confirmatory laboratory investigation during the period of this study. Establishing a surveillance system to study abortion outbreaks in Uruguay seems important to better understand the pathogenesis, epidemiology and best diagnostic techniques for leptospirosis and other abortive diseases in the country.

Viral abortions in cattle are reported in low frequencies in several studies (Vaucher et al. 2011, Clothier \& Anderson 2016). In this case series, one abortion was caused by BPI-3 virus. This agent had been previously isolated from a bovine fetus and the case diagnosed in our study has been published elsewhere (Macías-Rioseco et al. 2019b). Abortions due to BHV-1 and BVDV were not observed in this series, although BVDV RNA was detected in three fetuses. None of the three cases had lesions compatible to BVDV, and IHC reactivities for BVDV antigen in liver, small intestine and brain were negative. The molecular detection of the pathogen confirms the circulation of the virus in these herds. Even though it seems that BVDV was not responsible for the abortions in these cases, it is important to test affected herds to identify persistently infected animals and the possibility of the occurrence of other forms of BVDV-associated diseases in the farms. Two of the positive BVDV animals were also positive for $N$. caninum by PCR and/or IHC and in fact had tissue lesions consistent with neosporosis, that was considered the primary cause of the abortions. It has been suggested that BVDV infections allow other pathogens to easily cross the fetoplacental barrier, increasing the risk of abortion (Murray 1991, Quinn et al. 2004).

One abortion in our series was due to Salmonella Newport, which is rarely reported causing abortions (Campero et al. 2018). In this farm the serovar Newport also caused neonatal calf diarrhea and neonatal mortality due to septicemia during the same period (data not shown), indicating that the abortion was part of the spectrum of diseases typically associated with salmonellosis in dairy cattle and not an isolated event. In cattle, Salmonella enterica serovars Typhimurium, Dublin, and Newport are the most commonly cause of salmonellosis. 
The clinical disease can be enteritic and/or septicemic, the latter can result in abortion in pregnant cattle (Uzal et al. 2016, Campero et al. 2018, Costa et al. 2018). Abortions due to Salmonella are mostly associated with Salmonella Dublin (Campero et al. 2003), and less frequently, with $S$. Typhimurium (Easton 2006).

Other bacteria such us E. coli, Streptococcus spp., T. pyogenes, Staphylococcus spp. and Mannheimia spp. have previously been recognized as sporadic abortifacients in cattle, and as in other reports, were associated with suppurative lesions in the placenta, lungs, and occasionally other fetal tissues (Anderson et al. 1990, Campero et al. 2003, Clothier \& Anderson 2016, Campero et al.2018). One case was attributed to a congenital neoplasia (mesothelioma). While congenital neoplasia in cattle is very uncommon, mesothelioma is within the most frequently diagnosed cancers in bovine fetuses. Although mesotheliomas are of mesenchymal origin, they should be differentiated from disseminated metastatic adenocarcinomas. In adults the occurrence of mesotheliomas has been associated with exposure to asbestos, while this is less clear in fetuses (Peli et al. 2018).

\section{CONCLUSIONS}

Neosporosis is the main cause of abortions in the dairy cattle population that we studied.

Coxiellosis is a cause of outbreaks or sporadic cases of abortions in Uruguay.

Campylobacteriosis is still a cause of abortions, and most likely infertility in dairy cattle in the country.

It is important to further investigate the pathogenesis mechanisms, epidemiology and diagnosis of leptospirosis to determine the importance of this disease as a cause of abortion in Uruguay.

The systematic diagnosis of bovine abortion is necessary to set possible strategies of prevention and control, besides monitoring and surveillance of reproductive diseases in dairy cattle, some of which can represent a risk to public health.

\footnotetext{
Acknowledgments.- This research was financially supported by "Agencia Nacional de Investigación e Innovación” (ANII), grant FSSA_X_2014_1_105696. The authors thank Yisell Perdomo, Cecilia Monesiglio, Anderson Saravia, Bruno Lopez, and all graduate students from the animal health platform at INIA, Jennifer McKenna from UW, Francisco Uzal, Karen Sverlow and Juliann Beingesser from CAHFS-UC Davis for valuable assistance. We are grateful to Luis Corbellini, for his keen and valuable suggestions preparing the manuscript, Ximena Salaberry from the "Division de Laboratorios Veterinarios" (DILAVE) of the Uruguayan "Ministerio de Ganadería, Agricultura y Pesca" (MGAP), Santiago Mirazo from UdelaR, and Cecilia Nieves and Camila Hamond from the "Institut Pasteur", Montevideo.
}

Conflict of interest statement.- The authors declare that there are no conflicts of interest.

\section{REFERENCES}

Agerholm J.S. 2014. Coxiella burnetii and reproductive disorders in cattle. Infect. Genet. Evol. 28:150. <http://dx.doi.org/10.1016/j.meegid.2014.09.023> $<$ PMid:25261243>

Anderson M.L., Blanchard P.C., Barr B.C. \& Hoffman R.L. 1990. A survey of causes of bovine abortion occurring in the San Joaquin Valley, California. J. Vet. Diagn. Invest. 2(4):283-287. <http://dx.doi.org/10.1177/104063879000200405> $<$ PMid:2095280>
Antoniassi N.A.B., Juffo G.D., Santos A.S., Pescador C.A., Corbellini L.G. \& Driemeier D. 2013. Causas de aborto bovino diagnosticadas no Setor de Patologia Veterinária da UFRGS de 2003 a 2011. Pesq. Vet. Bras. 33(2):155160. <http://dx.doi.org/10.1590/S0100-736X2013000200004>

Bildfell R. J., Thomson G. W., Haines D. M., Beverly J. M. \& Smartet N. 2000. Coxiella burnetii infection is associated with placentitis in cases of bovine abortion. J. Vet. Diagn. Invest. 12(5):419-425. <http://dx.doi. org/10.1177/104063870001200505> <PMid:11021428>

Campero C.M., Cantón G. \& Moore D.P. 2018. Abortos y Otras Pérdidas Reproductivas en Bovinos: diagnóstico y control. Editorial Hemisferio Sur, Buenos Aires, p.41-46.

Campero C.M., Moore D.P., Odeón A.C., Cipolla A.L. \& Odriozola E. 2003. Aetiology of bovine abortion in Argentina. Vet. Res. Commun. 27(5):359369. <http://dx.doi.org/10.1023/a:1024754003432><PMid:14509450>

Chaban B., Garcia Guerra A., Hendrick S.H., Waldner C.L. \& Hill J.E. 2013. Isolation rates of Campylobacter fetus subsp. Venerealis from bovine preputial samples via passive filtration on nonselective medium versus selective medium, with and without transport medium. Am. J. Vet. Res. 74(8):10661069. <http://dx.doi.org/10.2460/ajvr.74.8.1066> <PMid:23879843>

Clothier K. \& Anderson M. 2016. Evaluation of bovine abortion cases and tissue suitability for identification of infectious agents in California diagnostic laboratory cases from 2007 to 2012. Theriogenology 85(5):933-938. <http:// dx.doi.org/10.1016/j.theriogenology.2015.11.001><PMid:26679514>

Corbellini L.G., Pescador C.A., Frantz F., Wunder E., Steffen D., Smith D.R. \& Driemeier D. 2006. Diagnostic survey of bovine abortion with special reference to Neospora caninum infection: importance, repeated abortion and concurrent infection in aborted fetuses in Southern Brazil. Vet. J. 172(1):114120. <http://dx.doi.org/10.1016/j.tvjl.2005.03.006><PMid:16772136>

Costa R.A., Casaux M.L., Caffarena R.D., Macías-Rioseco M., Schild C.O., Fraga M., Riet-Correa F. \& Giannitti F. 2018. Urocystitis and ureteritis in Holstein calves with septicaemia caused by Salmonella enterica serotype Dublin. J. Comp. Pathol. 164:32-36. <http://dx.doi.org/10.1016/j.jcpa.2018.08.005> $<$ PMid:30360910>

De Vries A. 2006. Economic value of pregnancy in dairy cattle. J. Dairy Sci. 89(10):3876-3875. <http://dx.doi.org/10.3168/jds.S0022-0302(06)72430-4> $<$ PMid:16960063>

Dilbeck P.M. \& McElwain T.F. 1994. Immunohistochemical detection of Coxiella burnetii in formalin-fixed placenta. J. Vet. Diagn. Invest. 6(1):125-127. <http://dx.doi.org/10.1177/104063879400600129><PMid:7516717>

Easton C. 2006. Estudio patológico de las principales causas de aborto bovino en Uruguay. Masters Thesis, Universidad de la República, Montevideo.

Figueiredo J.F., Pellegrin A.O., Fóscolo C.B., Machado R.P., Miranda K.L. \& Lage A.P. 2002. Evaluation of direct fluorescent antibody test for the diagnosis of bovine genital campylobacteriosis. Revta Latinoam. Microbiol. 44(3/4):118-123. <PMid:17063594>

Giakoumelou S., Wheelhouse N., Cuschieri K., Entrican G., Howie S.E. \& Horne A.W. 2016. The role of infection in miscarriage. Hum. Reprod. Update 22(1):116-133. <http://dx.doi.org/10.1093/humupd/dmv041> $<$ PMid:26386469>

Giannitti F., Anderson M., Miller M., Rowe J., Sverlow K., Vasquez M. \& Cantón G. 2016. Chlamydia pecorum: fetal and placental lesions in sporadic caprine abortion. J. Vet. Diagn. Invest. 28(2):184-189. <http://dx.doi. org/10.1177/1040638715625729> <PMid:26965241>

Hazlett M.J., McDowall R., DeLay J., Stalker M., McEwen, B., Van Dreumel T., Spinato M., Binnington B., Slavic D., Carman S. \& Cai H.I. 2013. A prospective study of sheep and goat abortion using real-time polymerase chain reaction and cut point estimation shows Coxiella burnetii and Chlamydophila abortus infection concurrently with other major pathogens. J. Vet. Diagn. Invest. 25(3):359-368. <http://dx.doi.org/10.1177/1040638713484729> $<$ PMid:23572455> 
INALE 2014. Instituto Nacional de la Leche. Encuesta Lechera (INALE). Available at <http://www.inale.org/innovaportal/v/3597/2/innova. front/ encuesta-lechera-inale-2014.html> Accessed on Dec. 21, 2018.

Lorenz H., Jäger C., Willems H., \& Baljer G. 1998. PCR detection of Coxiella burnetii from different clinical specimens, especially bovine milk, on the basis of DNA preparation with a silica matrix. Appl. Environ. Microbiol. 64(11):4234-4237. <PMid:9797270>

Macías-Rioseco M., Caffarena R.D., Fraga M., Silveira C., Giannitti F., Cantón G., Hecker H.P., Suanes A. \& Riet-Correa F. 2019a. Abortion outbreak caused by Campylobacter fetus subspecies venerealis and Neospora caninum in a bovine dairy herd. Revta Mexicana Cienc. Pecuarias 10(4):1054-1063. <http://dx.doi.org/10.22319/rmcp.v10i4.5008>

Macías-Rioseco M., Mirazo S., Uzal F.A., Fraga M., Silveira C., Maya L., RietCorrea F., Arbiza J., Colina R., Anderson M.L. \& Giannitti F. 2019b. Fetal pathology in an aborted Holstein fetus infected with bovine parainfluenza virus-3 genotype A. Vet. Pathol. 56(2):277-281. <http://dx.doi. org/10.1177/0300985818798117> <PMid:30244663>

Macías-Rioseco M., Riet-Correa F., Miller M.M., Sondgeroth K., Fraga M., Silveira C., Uzal F.A. \& Giannitti F. 2019c. Bovine abortion caused by Coxiella burnetii; report of a cluster of cases and review of the literature. J. Vet. Diagn. Invest. 31(4):634-639. <http://dx.doi.org/10.1177/1040638719856394> <PMid:31179891>

Maya L., Puentes R., Reolón E., Acuña P., Riet F., Rivero R., Cristina J.\& Colina R. 2016. Molecular diversity of bovine viral diarrhea virus in Uruguay. Arch. Virol. 161(3):529-535. <http://dx.doi.org/10.1007/s00705-0152688-4> <PMid:26597189>

McAllister M.M. 2016. Diagnosis and control of bovine neosporosis. Vet. Clin. N. Am., Food Anim. Pract. 32(2):443-463. <http://dx.doi.org/10.1016/j. cvfa.2016.01.012><PMid:27161392>

Meyer Zarzar L.P. 2013. Estudio descriptivo de las principales causas de aborto bovino diagnosticados entre los años 1990 y 2010 en el Instituto de Patología Animal de la Universidad Austral de Chile. Masters Thesis, Universidad Austral de Chile, Santiago, Chile. 34p.

Michi A.N., Favetto P.H., Kastelic J. \& Cobo E.R. 2016. A review of sexually transmitted bovine trichomoniasis and campylobacteriosis affecting cattle reproductive health. Theriogenology 85(5):781-791. <http://dx.doi. org/10.1016/j.theriogenology.2015.10.037><PMid:26679515>

Moennig V. \& Liess B. 1995. Pathogenesis of intrauterine infections with Bovine Viral Diarrhea Virus. Vet. Clin. N. Am., Food Anim. Pract. 11(3):477-487. <http://dx.doi.org/10.1016/s0749-0720(15)30462-x><PMid:8581858>

Moreira R.E.S., Caffarena R.M., Perez G., Somma S. \& Monteiro M. 1987. Fiebre "Q" en Uruguay. Revta Inst. Med. Trop. S. Paulo 29(3):168-173. <http:// dx.doi.org/10.1590/S0036-46651987000300009>

Morrell E. 2010. Caracterización diagnóstica de las causas infecciosas del aborto bovino. PhD Thesis, Universidad Nacional de La Plata, Buenos Aires.

Murray R.D. 1991. Lesions in aborted bovine fetuses and placenta associated with bovine viral diarrhea virus infection. Arch. Virol. 3(supl.1):217-224. <http://dx.doi.org/10.1007/978-3-7091-9153-8_26><PMid:9210944>

Peli A., Bolcato M., Roccaro M., Gentile A. \& Militerno G. 2018. Mesothelioma in cattle: two case reports. Large Anim. Rev. 24:89-92.
Piaggio J. 2006. Estudio transversal de neosporosis en la principal cuenca lechera del Uruguay. Masters Thesis, Universidad de la República, Montevideo Uruguay. 47p.

Quinn H.E., Windsor P.A., Kirkland P.D. \& Ellis J.T. 2004. An outbreak of abortion in a dairy herd associated with Neospora caninum and bovine pestivirus infection. Aust. Vet. J. 82(1/2):99-101. <http://dx.doi.org/10.1111/j.1751-0813.2004.tb14656.x><PMid:15088970>

Raghupathy R. 2001. Pregnancy: success and failure within the Th1/Th2/Th3 paradigm. Semin. Immunol. 13(4):219-227.<http://dx.doi.org/10.1006/ smim.2001.0316><PMid:11437629>

Schieve L.A., Handler A., Hershow R., Persky V. \& Davis F. 1994. Urinary tract infection during pregnancy: its association with maternal morbidity and perinatal outcome. Am. J. Public Health 84(3):405-410. <http://dx.doi. org/10.2105/ajph.84.3.405><PMid:8129056>

Silva M.S., Brum M.C., Loreto E.L., Weiblen R. \& Flores E.F. 2007. Molecular and antigenic characterization of Brazilian bovine herpesvirus type 1 isolates recovered from the brain of cattle with neurological disease. Virus Res. 129(2):191-199. <http://dx.doi.org/10.1016/j.virusres.2007.07.014> <PMid:17822796>

Silveira C.S. 2019. Enfermedades infecciosas que causan abortos en bovinos con enfoque en rodeos lecheros de Uruguay. PhD Masters Thesis, Universidad de la República, Montevideo. 135p.

Silveira C.S., Fraga M., Giannitti F., Macías-Rioseco M., \& Riet-Correa F. 2018. Diagnosis of bovine genital campylobacteriosis in South America. Front. Vet. Sci. 5:321. <http://dx.doi.org/10.3389/fvets.2018.00321> <PMid:30619902>

Uzal F.A., Plattner B.L. \& Hostetter J.M. 2016. Alimentary system, p.167-176. In: Maxie M.G. (Ed.), Jubb, Kennedy and Palmer's Pathology of Domestic Animals. Vol.2. 6th ed. Elsevier, St Louis, Missouri.

Vaucher R.A., Dezen D., Simonetti A.B., Spilki F.R., \& Roehe P.M. 2011. Phylogenetic characterization of bovine parainfluenza 3 from contaminated cell cultures and field isolates from Brazil. Braz. J. Microbiol. 42(4):1440-1444. <http:// dx.doi.org/10.1590/S1517-83822011000400029>

Yamage M., Flechtner 0. \& Gottstein B. 1996. Neospora caninum: specific oligonucleotide primers for the detection of brain "cyst" DNA of experimentally infected nude mice by the polymerase chain reaction (PCR). J. Parasitol. 82(2):272-279. <PMid:8604096>

Zarantonelli L., Suanes A., Meny P., Buroni F., Nieves C., Salaberry X., Briano C., Ashfield N., Da Silva Silveira C., Dutra F., Easton C., Fraga M., Giannitti F., Hamond C., Macías-Rioseco M., Menéndez C., Mortola A., Picardeau M., Quintero J., Ríos C., Rodríguez V., Romero A., Varela G., Rivero R., Schelotto F., Riet-Correa F. \& Buschiazzo A. 2018. Isolation of pathogenic Leptospira strains from naturally infected cattle in Uruguay reveals high serovar diversity and uncovers a relevant risk for human leptospirosis. PLoS Negl. Trop. Dis. 12(9): e0006694. <http://dx.doi.org/10.1371/journal. pntd.0006694> <PMid:30212451>

Zi M.Y., Longo P.L., Bueno-Silva B. \& Mayer M.P. 2015. Mechanisms involved in the association between periodontitis and complications in pregnancy. Front. Public Health 2:290.<http://dx.doi.org/10.3389/fpubh.2014.00290> $<$ PMid:25688342> 